https://doi.org/10.52240/1857-2367.2020.2(21).53

\title{
COLECŢIA DE PLANTE DIN FAMILIA ARECACEAE Sch.-Bip. A GRĂDINII BOTANICE NAŢIONALE (INSTITUT) „AL. CIUBOTARU”
}

\author{
Valentina ŢIMBALÎ, Victoria GUŞANOV \\ Grădina Botanică Naţională (I) " Al. Ciubotaru”, \\ Cihișinău, Republica Moldova
}

\begin{abstract}
During about 50 years, at the "Al. Ciubotaru" NBGI, the collection of plants of the Arecaceae family has been created and enriched; it currently includes 34 taxa, in 18 genera. Eleven taxa are able to reach the generative stage (flowering), and seven are able to produce fruits with seeds. The palm trees from the collection are propagated by seeds. Palm trees grow apically.
\end{abstract}

Key words: family, genus, species, Arecaceae, palm trees, collection, mobilization, introduction.

Familia Arecaceae Sch.-Bip., sau Palmae Juss. este una dintre cele mai numeroase familii de plante tropicale din clasa Liliopsida. Familia include 210 genuri şi cca 2500 specii [2], răspândite în regiunile tropicale şi subtropicale ale globului, insă cea mai bogată colecţie se află în Asia de Sud-Vest şi regiunile tropicale ale Americii de Sud. Palmierii alcătuiesc un element caracteristic al florei şi vegetaţiei țărilor tropicale, un component de bază al multor ecosisteme tropicale. Pentru locuitorii tărilor nordice palmierii sunt plante exotice, ce simbolizează regiunile tropicale, iar pentru cei din regiunile tropicale - un izvor important, uneori unicul, de existenţă a omului. După insemnatatea lor în viaţa omului, palmierii cedează numai gramineelor, iar după multitudinea de 
întrebuinţări nu au egali. Palmierii de cocos şi de ulei, de curmal şi de zahăr şi alţii fac parte din numărul de plante folosite de om din cele mai străvechi timpuri.

În prezent colecţia de palmieri a Gradinii Botanice Naţionale (I) "Al. Ciubotaru" numără 34 de taxoni, din 18 genuri sub formă de arbori şi arbuşti. Cel mai bine prezente sunt genurile: Chamaedorea Willd. (6 taxoni); Phoenix L. şi Sabal Adans. (câte 4 fiecare); Livistona R. Br.; Rhapis L. f. ex W. Aiton; Waschingtonia Z. Wendl. (câte 3 specii fiecare). Primele specii de palmieri în colecţie au fost: Chamaedorea elatior Mart., Chamaerops humilis L., Phoenix canariensis hort, Sabal palmetto Lodd. ex Schult., Trachycarpus excelsius $\mathrm{H}$. Wendl, Waschingtonia filifera $\mathrm{H}$. Wendl. La sfârșitul anilor 70 ai sec. XX colecţia numara 15 taxoni, din 11 genuri [1]. Restul taxonilor au fost introduşi în colecţie începând cu anii 80 ai secolului trecut şi până în prezent. Majoritatea speciilor au fost obţinute din seminţe primite prin intermediul Catalogului de seminţe (Index Seminum) din alte instituţii cu profil botanic din lume. Din cei 34 taxoni în condiţiile de seră ale GBN (I) faza generativă (înflorirea) ating 11 taxoni, iar fructe cu seminţe formează doar 7. Seminţele palmierilor sunt foarte deosebite după dimensiuni şi forme. Dimensiunile lor variază de la câţiva mm până la cele mai mari din lumea plantelor - 30 sau $45 \mathrm{~cm}$ şi greutatea $9 \mathrm{~kg}$ (palmierul de Seişel). În prezent în colecţie cresc şi se dezvoltă plantule de diferite specii de palmieri (Waschingtonia filifera, Chamaerops humilis), seminţele cărora au fost colectate din ţările cu climă mediteraniană (Turcia, Grecia), Licuala grandis H. Wendl., Wodyetia bifurcata A. K. Irvine, - insula Bali, Pritchardia pacifica $\mathrm{H}$. Wendl. - Zanzibar.

Pentru a capăta o germinaţie bună seminţele sunt încorporate în substrat îndată după coacere. Păstrarea seminţelor duce la micşorarea procentului de germinare a lor. Plantulele căpătate din seminţe au o creştere foarte lentă. Pe parcursul anilor, din serele GBN (I) au fost evacuate multe exemplare de palmieri Phoenix roebelinii O'Brien,Waschingtonia filifera etc. care au atins înălţimi, ce nu le permitea creşterea de mai departe în sere.

Teza este realizată în cadrul proiectului ,Cercetări privind mobilizarea diversității vegetale cu potenţial ornamental pentru conservarea ex-situ”

\section{BIBLIOGRAFIE SELECTIVĂ}

1. К. Ф. Дворянинова, В. И. Шестак Тропические и субтропические растения в оранжереях Ботанического Сада АН МССР: Кишинев «Штиинца», 1985, стр. 167-169.

2. Н. Н. Имханицкая Пальмы. Ленинград, Издательство Наука, Ленинградское отделение, 1985, 242 стр. 